\title{
Lingvistiline järjestuskatse polüseemia uurimise vahendina omadussõna vana semantilise analüüsi näitel
}

\author{
AIMI PIKKSAAR
}

Traditsiooniliselt mõistetakse polüseemia all nähtust, kus ühele fonoloogilisele vormile vastab kaks või enam omavahel seotud tähendust (Taylor 2003: 637). Kuigi igapäevases inimestevahelises kommunikatsioonis tekitab polüseemia harva probleeme, on see tõsiseks väljakutseks nii teoreetilistele kui ka rakenduslikele semantikakäsitustele: näiteks ühe ja sama sõna tähenduste loetlemisel ja nende alltähendusteks liigitamisel võivad eri sõnaraamatute koostajate arvamused erineda, samuti näevad tehisintellekti loojad ja arvutilingvistid palju vaeva polüseemsete sõnade semantiliste esituste väljatöötamisega (Ravin, Leacock 2000: 1-2). Käesoleva artikli fookuses on küsimus, kuidas luua niisugune polüseemse sõna semantiline kirjeldus, mis kajastaks seda, mismoodi emakeelekõnelejad intuitiivselt eristavad sõna tähendusi. Omadussõna vana polüseemia analüüsimise näitel on siin tutvustatud üht võimalust, kuidas jõuda sellise kirjelduseni katseliste meetodite abil.

Mõnes keeleteaduse valdkonnas (nt foneetikas) on katsete tegemisel pikk ajalugu, kuid semantikas ei ole katsed väga levinud olnud (Jürine jt 2013: 86). Katseliste meetodite kasutuselevõtmise vajadust tähenduste uurimisel hakkasid paarkümmend aastat tagasi rõhutama kognitiivse lingvistika esindajad (vt nt Sandra, Rice 1995). Enne seda oli semantiliste nähtuste valdavaks uurimismeetodiks introspektsioon ehk enesevaatlus, uurija isiklikule keeletajule toetuv keeleanalüüs. Kuna tähendusi pole olemas tähendust andva subjekti teadvusest eraldiseisvalt, siis on iga semantikaalase uurimistöö paratamatu ja hädavajalik osa introspektiivne analüüs, mis aga ei pea olema uurimisprotsessi ainus lüli. Viimastel aastakümnetel on järjest enam keeleteadlasi leidnud, et katsed on muude empiiriliste meetodite (nt korpusmeetodite ja neurolingvistiliste aju-uuringute) kõrval üks võimalus semantika uurimise meetodite mitmekesistamiseks. Katsed sobivad eriti hästi teiste meetodite abil tehtud järelduste kontrollimiseks, nagu on osutanud Jane Klavan jt (2013: 18). Katse läbiviimine eeldab üldjuhul hüpoteesi, mille aluseks sobib suurepäraselt introspektiivse analüüsi tulemus.

Siin uurimuses ongi kõigepealt loodud omadussõna vana semantika introspektsioonipõhine kirjeldus, kus vana tähenduse varieerumine on seostatud erinevate ajast arusaamise viisidega. Selline lähenemine tugineb kognitiivse lingvistika põhiseisukohale, mille järgi keelelisi tähendusi tuleb uurida arusaamade, ettekujutuste ja uskumuste kontekstis, mis keelekasutajatel on uuritava sõnaga seostuva maailmafragmendi kohta olemas (Õim 1990, 1997). Kognitiivseks valdkonnaks, mille taustal analüüsida vana tähendusi, sai valitud aeg seetõttu, et kõik vana tähendused seostuvad mingil määral muutumisega (sellele on otseselt juhtinud tähelepanu 
nt Rahhilina 1997: 203). Muutumine on aga omakorda seotud ajaga - aega on defineeritud muutuse kaudu juba alates Aristotelesest, kelle järgi aeg on „muutuse arv eelneva ja järgneva suhtes” (Aristotle 1993: 44, 219b1-2), ning ka moodsal füüsikal põhinevates filosoofilistes aruteludes, kus aega käsitatakse ühena aegruumi neljast mõõtmest, esindab aeg muutuse dimensiooni (Mellor 2003: 959).

Introspektsioonipõhise kirjelduse paikapidavuse kontrollimiseks - kas loodud mudel sobib kirjeldama seda, kuidas keelekasutajad teevad vahet uuritava sõna tähendustel - on siin uurimuses kasutatud järjestuskatset. ${ }^{1}$ Selle katsetüübi abil on edukalt kogutud andmeid uuritavate objektide omavaheliste sarnasussuhete kohta näiteks sotsiaalteadustes ja turu-uuringutes (Tsogo jt 2000: 314-315), kuid siinsele uurimusele ei olnud eeskujuks võtta ühtki keeleteaduslikku tööd, kus järjestuskatset oleks rakendatud tutvustamisele tuleval kombineeritud viisil. Katseandmete kogumisele järgneb nende analüüsimine ja tõlgendamine. Nagu muude empiiriliselt kogutud lingvistiliste andmete, nii on ka katsetulemuste analüüsimisel hakatud viimastel aastakümnetel nii maailma kui ka Eesti keeleteaduses järjest enam kasutama mitmesuguseid kvantitatiivse andmeanalüüsi meetodeid. ${ }^{2}$ Käesolevas uurimuses järjestuskatse tulemuste analüüsimiseks valitud mitmemõõtmelise skaleerimise meetodit (ingl multidimensional scaling, MDS) on küll lingvistikas varem kasutatud, kuid seda meetodit ei ole rakendatud koos tahkude teoorial (ingl facet theory) põhineva tõlgendusviisiga (millest kirjutan lähemalt artikli kolmandas osas).

Artikli eesmärk on niisiis tutvustada üht polüseemia uurimise jaoks sobivaks osutunud meetodite komplekti, mille keskmes on järjestuskatse. Artikkel koosneb viiest osast. Esimeses osas esitan omadussõna vana introspektsioonipõhise semantilise kirjelduse, mille tulemused on katsega kontrollitava hüpoteesi aluseks. Teises osas tutvustan lähemalt järjestuskatset, tuues välja ka järjestuskatse kui katsetüübi eelised seni tähenduste uurimiseks palju kasutatud keeleüksuste paariviisilise võrdlemise ja sorteerimiskatse ees. Kolmandas osas annan kõigepealt lühikese ülevaate mitmemõõtmelisest skaleerimisest ja tahkude teooriast ning seejärel rakendan neid meetodeid sõna vana kohta järjestuskatsega kogutud andmete analüüsimiseks. Empiirilise uurimuse eesmärk on kontrollida katsetulemuste kokkusobivust introspektsiooni teel loodud sõna vana polüseemia kirjeldusega. Neljandas osas arutlen metodoloogiliselt tervikliku uurimisprotsessi üle ja toon välja järeldused, mida saadud tulemuste põhjal teha saab, ning viiendas osas esitan kokkuvõtte.

\section{Omadussõna vana semantika introspektiivne analüüs}

Omadussõna vana semantika introspektsioonipõhise mudeli loomise aluseks oli oletus, et sõna vana erinevate tähenduste olemasolu on tingitud sellest, et keelekasutajad toetuvad selle sõna tarvitamisel eri situatsioonides erinevatele ajaga seotud arusaamadele. Võimalike ajast arusaamise viiside väljaselgitamisel võtsin aluseks

\footnotetext{
${ }^{1}$ Järjestuskatse ja selle erinevate alatüüpide kohta vt pikemalt Tsogo jt 2000 või Rao, Katz 1971.

${ }^{2}$ Näiteks Keele ja Kirjanduse 2018. aasta teemanumber 8-9 oli pühendatud teoreetilise keeleteaduse ja kvantitatiivsete meetodite omavahelistele suhetele (Veismann jt 2018).
} 
ajamõiste kujunemist käsitlevad kultuuriajaloolaste tööd (nt Gurevitš 1968, 1992; Klein 1999; Aarelaid 1977; Vahtre 1991; Ingold 1986; vt ülevaadet Pikksaar 2012: 12-19). Sõna vana võimalike tähenduste otsimisel toetusin seletavale sõnaraamatule (EKSS 2009), vana võorkeelsete vastete kohta tehtud uurimustele (Rahhilina 1997; Bouillon 1999; Taylor 1992) ning Tartu Ülikooli eesti kirjakeele korpusele (TÜKK). Kvalitatiivse korpusvaatluse vormis (ilma statistilise analüüsita) vaatasin läbi umbes 700 vana sisaldavat lauset, kasutades sealt saadud andmeid niisuguste tähenduste väljatoomiseks, mida EKSS-is ega varasemates uurimustes polnud mainitud, aga mis sobisid minu süsteemis iseseisvate tähendusvälja piirkondadena esitamiseks.

Sõna vana erinevaid tähendusi võrreldes leidsin, et paljudest tähendustest on võimalik moodustada paare, mille liikmed seostuvad selgelt vastandlike arusaamadega ajast. Sellest kasvas välja idee vaadata kogu vana tähendusvälja vastandlike ajast arusaamise viiside valguses ning sobitada kõik vana tähendused ühte terviklikku süsteemi. Kõigi tähendusvariantide üksteisest eristamise jaoks pidasin oluliseks nelja vastandpaari (kokku kaheksat ajast arusaamise viisi). Tabelis 1 on esitatud nende vastandpaaride lühitutvustus koos sõrendusega esile tõstetud olulisemate paarisiseste vastandustega ning näitefraasidega. Kuna introspektsioonipõhisesse mudelisse valitud omadussõna vana iga tähendust on võimalik seostada iga vastandpaariga, siis võib sama fraas esindada mitut mittevastanduvat aega.

Tabelis 1 tutvustatud neli vastandpaari jagavad vana tähendusvälja neljal erineval moel kaheks pooleks (vt joonist 1, kus igal alamjoonisel on ajast arusaamise viisi nimetus ja sellele vastav tähendusvälja piirkond esitatud sama värviga - mustaga või halliga). Näiteks on esimeselt alamjooniselt näha, et tähendusvälja vasak pool toetub JÄRGNEVUSEL PÕHINEVALE AJALE ja tähendusvälja parem pool KESTUSEL PÕHINEVALE AJALE.

(1) KESTUSEL PÕHINEV AEG -

(1) JÄRGNEVUSEL PÕHINEV AEG

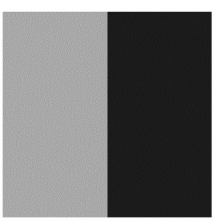

(3)

POSITIIVSELT VÄÄRTUSTATUD MINEVIKUGAAEG -

POSITIIVSELT VÄ̈RTUSTATUD TULEVIKUGAAEG

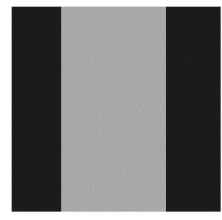

AJASTUGA SEOTUD MUUTUSEL PÕHINEV AEG -

INDTVTDUAAISE OBJEKTIGA SEOTUT MUTUTUSEL PÕHTINEV AEG

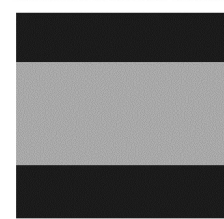

(4)

SUBJEKTIVÄLINE AEG -

SUJEKTISISENE AEG

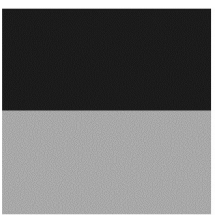

Joonis 1. Omadussõna vana tähendusväli liigendatuna ajast arusaamise viiside nelja vastandpaariga. 
Tabel 1. Ajast arusaamise viiside neli vastandpaari, mis võimaldavad introspektsioonipõhises mudelis vana tähendusi eristada.

\begin{tabular}{|c|c|c|}
\hline \multirow[t]{5}{*}{1.} & KESTUSEL PÕHINEV AEG $\rightarrow$ & $\leftarrow$ JÄRGNEVUSEL PÕHINEV AEG \\
\hline & - vaadeldakse üht objekti & - vaadeldakse kaht (või enamat) objekti \\
\hline & $\begin{array}{l}\text { - võrreldakse objekti ajalist kestust antud } \\
\text { liiki objektide keskmise eksisteerimis- } \\
\text { ajaga }\end{array}$ & $\begin{array}{l}\text { - võrreldakse objektide omavahelisi suhteid } \\
\text { ajaliselt üksteisele järgnevate objektide seerias }\end{array}$ \\
\hline & $\begin{array}{l}\text { vanaks nimetatakse objekti, mis on } \\
\text { eksiste erinud suhteliselt kau a } \\
\text { a ega, nt vana naine }\end{array}$ & $\begin{array}{l}\text { - vanaks nimetatakse objekti, mis on mingist } \\
\text { samalaadsest hilise mast objektist } \\
\text { varasem, nt vana juhataja }\end{array}$ \\
\hline & $\begin{array}{l}\text { - objekti u us/noor se is und e elneb } \\
\text { vanale seisundile }\end{array}$ & - vana objekt e elneb u uele objektile \\
\hline \multirow[t]{6}{*}{2.} & $\begin{array}{l}\text { AJASTUGA SEOTUD MUUTUSEL PÕHINEV } \\
\text { AEG } \rightarrow\end{array}$ & $\begin{array}{l}\text { —INDIVIDUAALSE OBJEKTIGA SEOTUD } \\
\text { MUUTUSEL PÕHINEV AEG }\end{array}$ \\
\hline & $\begin{array}{l}\text { - vaadeldakse kas mingit p e ri o o dili- } \\
\text { s elt muutuvat objekti või mingi objek- } \\
\text { tide klassi mingit eksistentsi t s ü klit } \\
\text { ehk ajastut esindavat objekti }\end{array}$ & $\begin{array}{l}\text { - vaadeldakse objekti a i n u kor d s e t eksis- } \\
\text { tentsi }\end{array}$ \\
\hline & - vanaks nimetatakse objekti, mis seostub & - vanaks nimetatakse objekti, mille \\
\hline & $\begin{array}{l}\text { 1) vaatlushetkeks kaua aega kestnud } \\
\text { ajaperioodiga (tähendused, mis } \\
\text { toetuvad esimese vastandpaari } \\
\text { KESTUSEL PõHINEVALE AJALE), nt } \\
\text { vana kuu }\end{array}$ & $\begin{array}{l}\text { 1) individuaalne eksistents on kestnud } \\
\text { kaua (tähendused, mis toetuvad esimese } \\
\text { vastandpaari KESTUSEL PõHINEVALE } \\
\text { AJALE), nt vana naine }\end{array}$ \\
\hline & $\begin{array}{l}\text { 2) vaatlushetke ajastule eelnenud } \\
\text { ajastuga (tähendused, mis toetuvad } \\
\text { esimese vastandpaari JäRGNEVUSEL } \\
\text { PõHINEVALE AJALE), nt vana kaevan- } \\
\text { damismeetod }\end{array}$ & $\begin{array}{l}\text { 2) kõrvale/asemele on ilmunud samalaadne } \\
\text { uus üksikobjekt (tähendused, mis toetuvad } \\
\text { esimese vastandpaari JäRGNEvUSEL } \\
\text { PÕHINEVALE AJALE), nt vana juhataja }\end{array}$ \\
\hline & $\begin{array}{l}\text { - vana objekt on vanaks tunnistatud } \\
\text { aja stu tüüpiline esindaja }\end{array}$ & $\begin{array}{l}\text { - objekti vanaks olemine on seotud tema indi- } \\
\text { viduaalse eksistentsiga }\end{array}$ \\
\hline \multirow[t]{3}{*}{3.} & $\begin{array}{l}\text { POSITIIVSELT VÄÄRTUSTATUD } \\
\text { MINEVIKUGA AEG } \rightarrow\end{array}$ & $\begin{array}{l}\leftarrow \text { POSITIIVSELT VÄÄRTUSTATUD TULEVIKUGA } \\
\text { AEG }\end{array}$ \\
\hline & $\begin{array}{l}\text { - väärtustatakse kaugesse minevikku jää- } \\
\text { vat algust }\end{array}$ & $\begin{array}{l}\text { - väärtustatakse seda, millel on ees tõenäoliselt } \\
\text { pikk tulevik ehk mille lõpp jääb vaatlushetkest } \\
\text { võimalikult kaugele }\end{array}$ \\
\hline & $\begin{array}{l}\text { - vana, mis seostub alati minevikuga, võib } \\
\text { saada vähemal või rohkemal määral } \\
\text { positiivse tä hend u svarju ndi, } \\
\text { nt vana tegija }\end{array}$ & $\begin{array}{l}\text { - vana, mis ei seostu tulevikuga, saab sageli } \\
\text { n egatii v s tä he nd u svar ju n d i, nt } \\
\text { vana kaevandamismeetod }\end{array}$ \\
\hline \multirow[t]{3}{*}{4.} & SUBJEKTIVÄLINE AEG $\rightarrow$ & $\leftarrow$ SUBJEKTISISENE AEG \\
\hline & $\begin{array}{l}\text { - vaadeldav objekt on seotud objektiiv- } \\
\text { selt jälgitavate muutustega }\end{array}$ & $\begin{array}{l}\text { - vaadeldav objekt on seotud muutusega, mille } \\
\text { toimumine on talletatud konkreetse(te) } \\
\text { subjekti(de) teadvuses }\end{array}$ \\
\hline & $\begin{array}{l}\text { - objekti vanaks olemine on tuvastatav } \\
\text { kõigile vaatlejatele kättesaadavate, vaat- } \\
\text { lusolukorras endas ilmnevate faktide } \\
\text { alusel, nt vana särk }\end{array}$ & $\begin{array}{l}\text { - objekti vanaks olemine pole vaatlushetkel } \\
\text { tuvastatav objektiivse vaatluse teel (ilma tead- } \\
\text { misteta varasema olukorra kohta), nt vana nali }\end{array}$ \\
\hline
\end{tabular}

Joonisel 1 esitatud neli liigendust saab ka kõik korraga tähendusväljale kanda: sel juhul on seal võimalik eristada kokku 16 väiksemat alampiirkonda, millega ma viisingi vastavusse EKSS-ist, varasematest uurimustest ja korpusest leitud vana tähen- 
dused (vt joonist 2). Kuna ka teise ja kolmanda vastandpaari kaks servaalade tükki (joonisel 1 hallist alast kahele poole jäävad musta värvi alad) moodustavad tegelikult ühe tervikala, siis tuleks tähendusvälja eri piirkondade omavahelistest suhetest täieliku pildi saamiseks keerata jooniseid 1 ja 2 vaadates mõtteliselt välja parem ja vasak äär omavahel kokku (tekib toru kujund) ning seejärel tuleks kokku keerata ka välja ülemine ja alumine äär (moodustub sõõrikutaoline kujund) - vt joonist 3. Tähendusvälja servade kokkukeerdumist on oluline meeles pidada hiljem naabertähendusteks olemise jälgimisel (nt tähendused 2 ja 9 või 9 ja 10 ei paikne joonise 2 kahemõõtmelisel pildil üksteise kõrval, kuid on selles mudelis siiski vahetud naabrid).

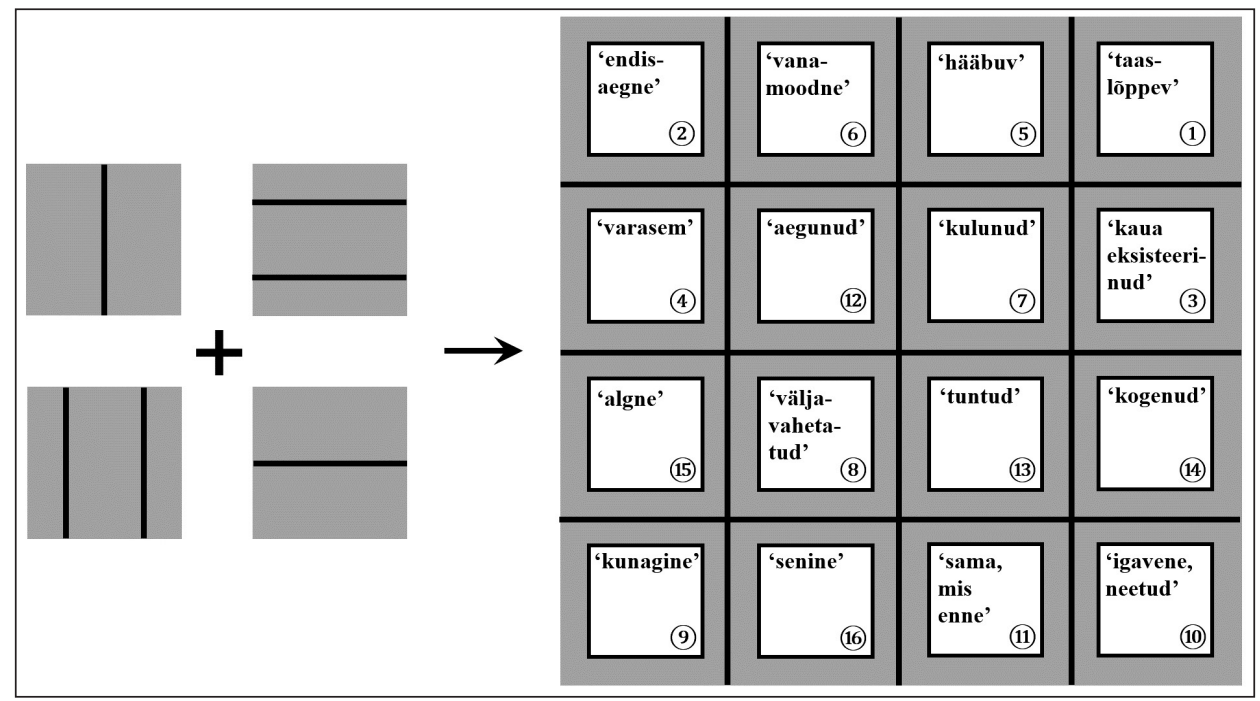

Joonis 2. Ajast arusaamise viiside nelja vastandpaari abil eristatud vana tähendusvälja 16 alampiirkonda koos lühikirjeldustega.

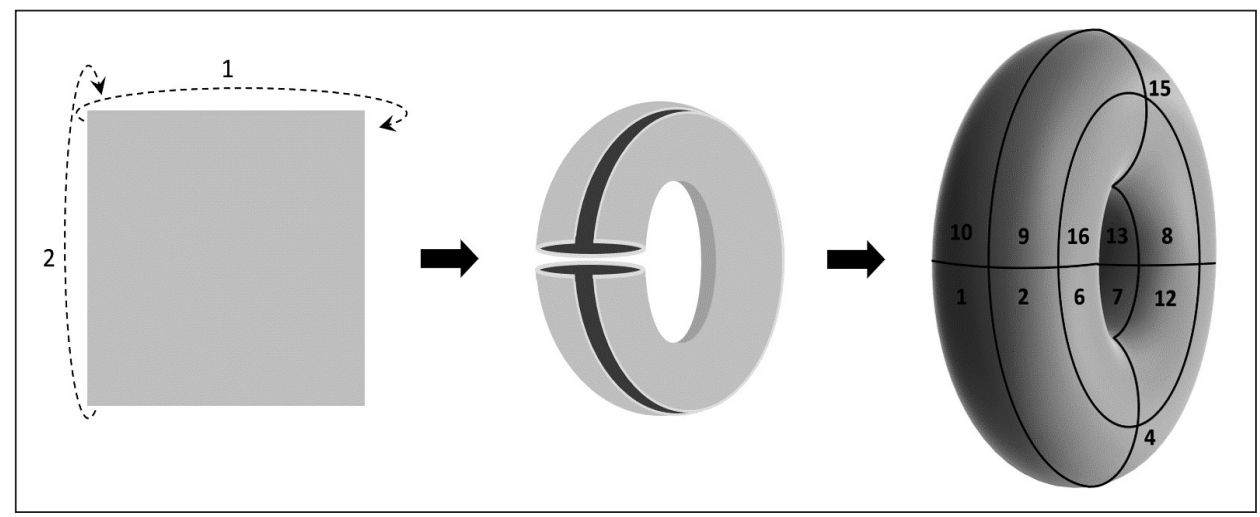

Joonis 3. Joonisel 2 esitatud tähendusväli 3D-mudelina. 
Kuna lähtusin seisukohast, et sageli on raske tõmmata selget piiri n-ö puhta polüseemia ja tähenduse ähmasuse vahele (vt nt Geeraerts 1993), siis tuleb silmas pidada, et tarvitades terminit tähendus joonistel 2 ja 3 välja toodud alampiirkondadele viitamiseks, ei ole ma eeldanud, et kõik neist oleks ka keelekasutajate meelest tingimata eraldiseisva üksuse staatuses tähendused, vaid pigem on need alad, mida minu mudeli alusel on teoreetiliselt võimalik eristada. Igaüks neist tähendustest toetub samaaegselt neljale ajast arusaamise viisile. Näiteks joonisel 2 paremas ülanurgas asuva tähenduse 1 'taaslõppev' aluseks on kõigist vastandpaaridest paari esimene (joonisel 1 musta värviga tähistatud) kategooria: KESTUSEL PõHINEV AEG, AJASTUGA SEOTUd MUUTUSEL PÕHINEV AEG, POSITIIVSELT VÄÄRTUSTATUD MINEVIKUGA AEG ja subJEkTIVÄLINE AEG. Mida lähemal kaks tähendust tähendusväljal teineteisele paiknevad, seda sarnasemad nad omavahel peaksid olema, sest seda suurem on nende aluseks olevate ajast arusaamise viiside kombinatsioonide ühisosa. Vahetuteks naabriteks olevad tähendused eristuvad teineteisest ainult ühe vastandpaari alusel. Näiteks tähendus 1 'taaslõppev' ja tähendus 3 'kaua eksisteerinud' erinevad üksnes selle poolest, et esimese aluseks on AJASTUGA SEOTUD MUUTUSEL PÕHINEV AEG, aga teisel INDIVIDUAALSE OBJEKTIGA SEOTUD MUUTUSEL PÕHINEV AEG (vt jooniseid 2 ja 1).

Introspektsioonipõhise mudeli tähenduspiirkondadele viitamiseks kasutan joonisel 2 esitatud tähenduste kastikeste alumises paremas nurgas olevaid numbreid. Nende numbrisiltide määramisel toetusin enda tehtud oletusele, millises järjekorras vana tähendused võisid keelde tulla: oletatavalt varasemad tähendused said väiksema ja hilisemad tähendused suurema numbriga sildi (vt pikemalt Pikksaar 2012: 29-32, 2016: 56-61). Käesolevas artiklis võib aga neid numbreid võtta kui lihtsalt identifitseerivaid silte, sest siinne uurimus keskendub hüpoteetilise diakroonilise arengu asemel selle väljaselgitamisele, kas eespool tutvustatud introspektsioonipõhine mudel annab adekvaatselt edasi vana tähenduste omavahelisi suhteid sünkroonses plaanis. Selleks otsustasin kontrollida, kas eesti keele kõnelejad tajuvad vana tähenduste sarnasussuhteid samamoodi, nagu minu loodud mudel neid suhteid kirjeldab, või mitte. Kontrollimise vahendina kasutasin lingvistilist järjestuskatset, mida tutvustan artikli järgmises osas.

\section{Omadussõna vana polüseemia uurimiseks läbiviidud järjestuskatse}

\subsection{Katse ülesehitus}

Katse viisin läbi 2016. aasta talvel. Katseisikuteks olid 16 Tartu Ülikooli humanitaarerialade üliõpilast (13 naist ja 3 meest). Kõigi katseisikute emakeel oli eesti keel ja nende keskmine vanus oli 24 aastat (noorim 20, vanim 33). Katsematerjaliks olid tabelis 2 esitatud reaalsest kirjalikust keelekasutusest pärit 16 lauset, mis kõik sisaldasid sõna vana nimisõnafraasis täiendi positsioonis. 
Tabel 2. Introspektsioonipõhisesse mudelisse kuuluvaid vana tähendusi esindama valitud laused järjestuskatses.

\begin{tabular}{|c|c|c|}
\hline $\begin{array}{l}\text { Tähendusvälja } \\
\text { piirkonna } \\
\text { number }\end{array}$ & $\begin{array}{l}\text { vana } \\
\text { tähenduse } \\
\text { lühikirjeldus }\end{array}$ & Katselause $^{3}$ \\
\hline 1 & 'taaslõppev' & $\begin{array}{l}\text { Ainult vanaisa räägib veel vundamendi rajamisest ja majapalgi } \\
\text { langetamisest vana kuu ajal. }\end{array}$ \\
\hline 2 & 'endisaegne' & Hoidke au sees vanu töövõtteid, tehke ise juustu ja leiba. \\
\hline 3 & $\begin{array}{l}\text { 'kaua eksistee- } \\
\text { rinud' }\end{array}$ & $\begin{array}{l}\text { Jõudsime sinna õhtul, kui hulk musta riietatud vanu naisi } \\
\text { parajasti kirikusse läks. }\end{array}$ \\
\hline 4 & 'varasem' & $\begin{array}{l}\text { Võimalik, et vana tõlge kipub nüüdisaja keskmise inimese } \\
\text { keeletajule juba liiga keeruliseks muutuma, ent uus peaks küll } \\
\text { olema kõigile mõistetav. }\end{array}$ \\
\hline 5 & 'hääbuv' & $\begin{array}{l}\text { Eemal ulgumerel nähti veel vaibuva põhjatuule jälgi: kerget } \\
\text { vana laine kohamist karidel, laiad väljad vaikivat vett. }\end{array}$ \\
\hline 6 & 'vanamoodne' & $\begin{array}{l}\text { Ahtme kaevanduses, mis on põlevkivibasseini üheks eesrind- } \\
\text { likumaks kaevanduseks, on täiesti loobutud igasugustest } \\
\text { vanadest kaevandamismeetodeist. }\end{array}$ \\
\hline 7 & 'kulunud' & $\begin{array}{l}\text { Käristasime mõned vanad särgid siiludeks ja sidusime tarale } \\
\text { lipendama. }\end{array}$ \\
\hline 8 & 'väljavahetatud' & $\begin{array}{l}\text { Kui ettevõttes vahetub juhataja, kas siis tuleb töötajate } \\
\text { töölepingud ümber teha, kuna vana juhataja sõlmis lepingud ja } \\
\text { töötajad allusid temale? }\end{array}$ \\
\hline 9 & 'kunagine' & $\begin{array}{l}\text { Vanade uskumuste järgi andis mingi asja päritolu teadmine } \\
\text { inimesele võimu selle asja üle. }\end{array}$ \\
\hline 10 & $\begin{array}{l}\text { 'igavene, } \\
\text { neetud' }\end{array}$ & $\begin{array}{l}\text { Sa vana siga ei kuivatanud hommikul vannitoa põrandat ära ja } \\
\text { ma ei saanud sellepärast dušsi alla minna. }\end{array}$ \\
\hline 11 & $\begin{array}{l}\text { 'sama, mis } \\
\text { enne' }\end{array}$ & $\begin{array}{l}\text { Tema tervis oli koormusele enam-vähem vastu pidanud, } \\
\text { vahepeal andis tunda vana seljahäda. }\end{array}$ \\
\hline 12 & 'aegunud' & $\begin{array}{l}\text { Mitmete õigete tähelepanekute kõrval püsib Wiedemann } \\
\text { vanale prosoodiakäsitlusele omasel seisukohal, et eesti keeles } \\
\text { on sõnarõhuline silp sõnarõhutust silbist umbes kaks korda } \\
\text { pikem. }\end{array}$ \\
\hline 13 & 'tuntud' & $\begin{array}{l}\text { See on juba vana nali, et kui tahad ära tunda pärnakat, siis } \\
\text { vaata suvel, kes on kõige valgema nahaga, see ongi ilmselt } \\
\text { pärnakas. }\end{array}$ \\
\hline 14 & 'kogenud' & $\begin{array}{l}81 \text { kg kaalus oli parim vana tegija Valeri Semiskur (Narvast), } \\
\text { kes alistas jõhvlase Deniss Kondrashovi ilmse ülekaaluga. }\end{array}$ \\
\hline 15 & 'algne' & $\begin{array}{l}\text { Paljud maailmakuulsad kunstiteosed on järeltulevatele } \\
\text { põlvedele sälinud koopiatena, mälestusmärgile tagaks ehtsuse } \\
\text { selle püstitamine vanasse kohta. }\end{array}$ \\
\hline 16 & 'senine' & $\begin{array}{l}\text { Keegi ei taha loobuda ei oma võimupiirkonnast, ei materiaal- } \\
\text { setest vahenditest ega ametikohtadest - ning reform taandubki } \\
\text { ringmängule vanas struktuuris. }\end{array}$ \\
\hline
\end{tabular}

${ }^{3}$ Tähendusi 8 ja 10 esindama valitud laused on saadud internetifoorumitest, tähendust 5 esindab EKSS-is (2009) sõna vana kirjes kasutusnäitena esitatud lause ühest August Mälgu teosest, ülejäänud laused on pärit korpusest (TÜKK). 
Iga katselause esindas üht introspektsioonipõhise mudeli vana tähendust. Sõna vana oli kõigis lausetes alla joonitud ja paksus kirjas. Iga lause oli trükitud eraldi sedelile. Sedelid olid pakendatud 16 kaupa ümbrikutesse ja igas ümbrikus oli ühele lausele kast ümber tehtud. Katseülesandeks oli järjestada ülejäänud 15 (ilma kastita) lausesedelit vana tähenduste sarnasuse alusel nii, et esimesele kohale tuli asetada lause, mille vana tähendus tundus katseisiku jaoks olevat kõige sarnasem kastiga ümbritsetud nn standardlause vana tähendusega, ja 15. kohale tuli panna lause, mille vana tähendus tundus olevat sellest kõige erinevam (vt joonist 4a). Kui igale lausele oli järjestuses koht leitud, siis tuli sedelitele järjekorranumbrid peale kirjutada ja sedelid ümbrikusse tagasi panna. Iga katseisik pidi järjestama nelja ümbriku sisu.

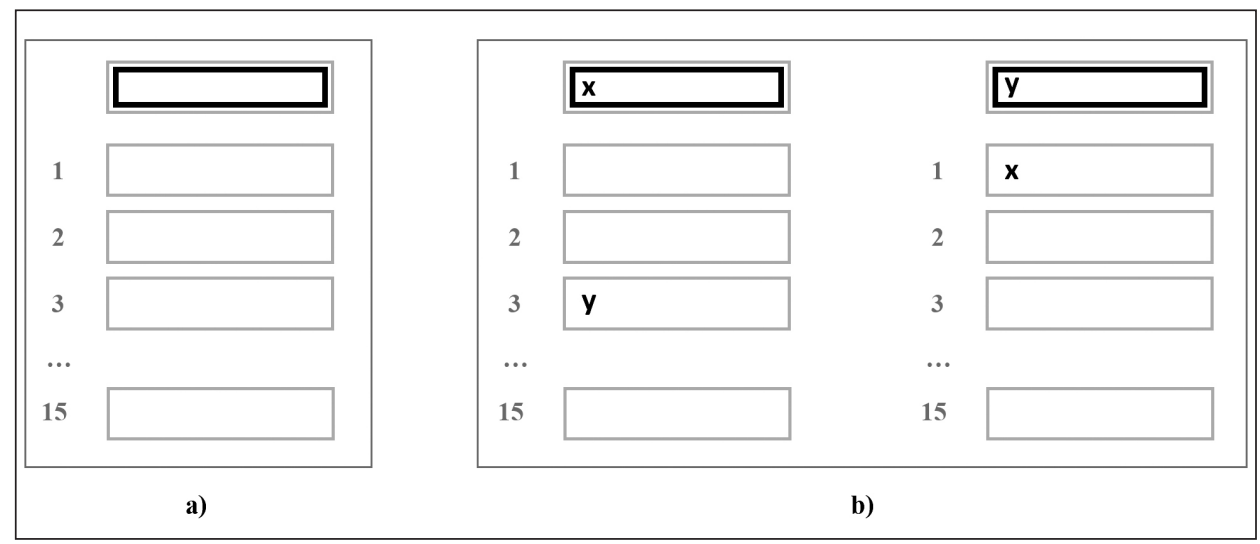

Joonis 4. Katselausete sedelite järjestamise skeem: a) üldskeem (kastiga ümbritsetud standardlause sedel ja selle suhtes järjestatud ülejäänud lausete sedelid); b) näide kahe tähenduse $x$ ja $y$ omavahelise sarnasussuhte kohta saadud hinnangutest.

Järjestuskatse kasuks otsustasin seetõttu, et see ühendab kahe seni tähenduste uurimiseks palju kasutatud katsetüübi - keeleüksuste paariviisilise võrdlemise ja sorteerimiskatse (vt nt Sandra, Rice 1995; Tsogo jt 2000) - tugevad küljed, kompenseerides sellega mõlema nõrku külgi. Paariviisilise võrdlemise plussiks on põhjalikkus: igat uuritavasse kogumisse kuuluvat objekti on võimalik võrrelda ükshaaval iga teise objektiga selles kogumis, saades niiviisi mingil etteantud skaalal omistatud hinnangu iga paari kahe liikme omavahelisele sarnasusele. Selle katsetüübi olulisteks puudusteks on esiteks suur ajakulu ja teiseks oht, et igal hinnangu andmise hetkel ainult ühele objektipaarile keskendudes võib objektide kogumi tervikpilt kaotsi minna ja hindamise alus pika katse käigus muutuda. Sorteerimiskatses on katseisikul kogu aeg kõik objektid silme ees ning katse sooritamisele kuluvat aega hoiab oluliselt kokku see, et üheainsa sorteerimisoperatsiooniga saab koguda hinnanguid kõikide objektide omavahelistele sarnasussuhetele. Sorteerimiskatse nõrkusena tooksin aga välja selle, et katseisiku jaoks probleemsete objektide grupikuuluvuse üle otsustamisel mängu tulev suvalisus avaldab lõpptulemusele suuremat segavat mõju kui sarnane otsustamisel ilmnev ebakindlus näiteks järjestuskatses. Põhjus on 
selles, et sorteerimiskatses moodustatud rühmad on eraldiseisvad üksused ja otsuses ei kajastu see, milliste gruppide vahel katseisik enda jaoks valiku tegema pidi. Järjestuskatses tuleb aga katseisiku mõtteviis tendentsina esile isegi siis, kui ta oma otsuses päris kindel ei olnud, nt kahtluse korral, kas paigutada mingi objekt teisele, kolmandale või neljandale kohale, väljendab tulemus (olenemata sellest, millise konkreetse otsuse katseisik lõpuks vastu võttis) kokkuvõttes ikkagi seda, et objekt asetati pigem järjestuse algusesse, mitte lõppu. Objektidevahelistele sarnasustele antavate hinnangute skalaarne olemus teeb järjestuskatse seega lähedasemaks paariviisilisele võrdlemisele. Samuti on viimasega sarnaselt järjestuskatseski korraga (igal üksikul järjestamiskorral) fookuses üksainus objekt ja selle suhted kogumi teiste üksikobjektidega, samal ajal antakse hinnanguid sarnaselt sorteerimiskatsega siiski kogu aeg ka objektide kogumi tervikut silmas pidades, sest järjestada tuleb kõik kogumisse kuuluvad objektid. Ajakulult jääb järjestuskatse paariviisilise võrdlemise ja sorteerimiskatse vahepeale.

\subsection{Katsetulemused}

Omadussõna vana polüseemia uurimiseks läbiviidud järjestuskatses sai iga katselause olla standardlause rollis neli korda. Nii kogunes igale kahest tähendusest $x$ ja $y$ koosnevale paarile kaheksa hinnangut: neli hinnangut standardlauses esinenud $x$-i suhtes järjestatud $y$-i järjekorranumbrina ja neli hinnangut standardlauses esinenud $y$-i suhtes järjestatud $x$-i järjekorranumbrina (vt joonist $4 \mathrm{~b}$, kus vasakpoolne järjestus annab tähenduste paarile $x$ ja $y$ hinnanguks 3 ning parempoolne 1). Seejärel leidsin nende kaheksa hinnangu (ehk järjekorranumbri) aritmeetilise keskmise, mille kandsin ruudukujuliseks tabeliks korrastatud distantsimaatriksisse (vt tabelit 3), kus igal tähendusel on oma rida ja oma veerg ning rea ja veeru ristumiskohas asub vastavate tähenduste omavahelisele sarnasussuhtele antud hinnangute keskmine väärtus. ${ }^{4}$ Distantsimõõduna on siin uurimuses kasutatud erinevusmõõtu, st suuremad väärtused distantsimaatriksis näitavad suuremat erinevust, kuna statistikaprogrammid, millega distantsimaatrikseid analüüsida saab, eelistavad enamasti sisendina erinevuste, mitte sarnasuste maatriksit. Distantsimaatriksi diagonaalid on nullid (erinevus iseendast puudub) ja maksimaalne võimalik väärtus oli selles järjestuskatses 15.

Järjestuskatse otseseks tulemuseks olid niisiis katseisikute hinnangud vana tähenduste omavahelistele erinevustele. Minu eesmärk oli aga välja selgitada, kas nende hinnangute andmisel võisid katseisikud toetuda intuitiivselt mingisugustele tunnustele, mis on kokku viidavad minu introspektsioonipõhises mudelis vana tähenduste üksteisest eristamiseks kasutatud tunnustega - ajast arusaamise viiside nelja vastandpaariga. Selle väljaselgitamiseks analüüsisin katsetulemusi mitmemõõtmelise skaleerimise meetodiga ning kasutasin tulemuste tõlgendamiseks tahkude teooriat. Artikli järgmises osas tutvustan mõlemat lähenemist kõigepealt teoreetilisest vaatepunktist ja seejärel rakendan neid sõna vana järjestuskatse tulemustele.

\footnotetext{
${ }^{4}$ Distantsimaatriksi kohta vt lähemalt nt Tooding 2015: 365; Kruskal, Wish 1978: 74-77.
} 


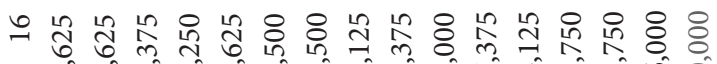

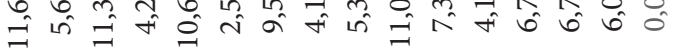

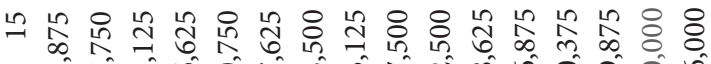
बे

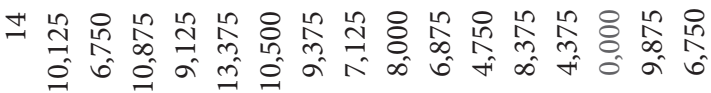

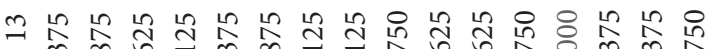

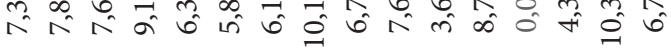

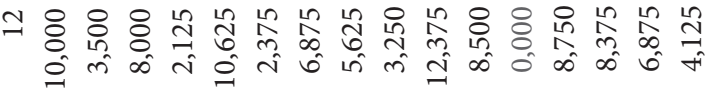

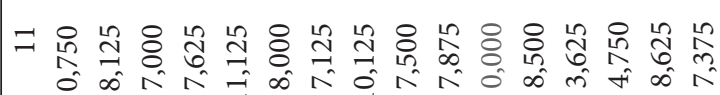

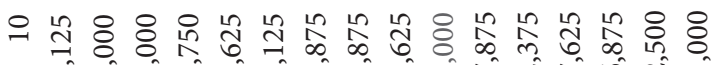
$\Rightarrow=\infty$ वी

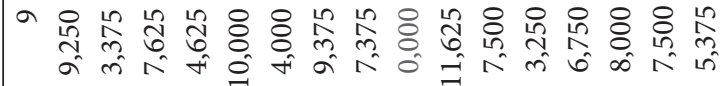

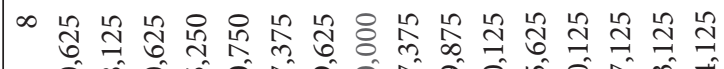

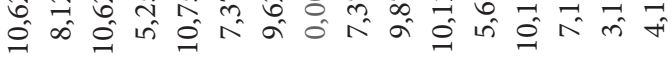

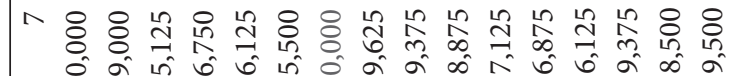

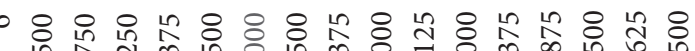
$\exists$ mे

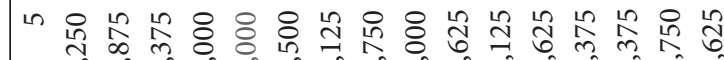
iी

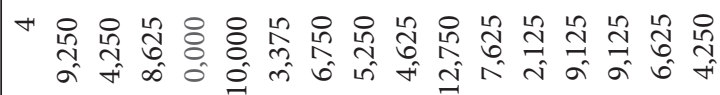

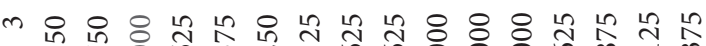

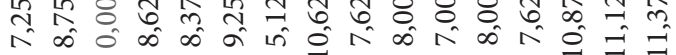

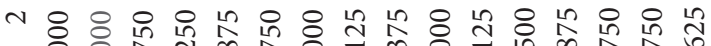
$\exists=0$ क ने

- 


\section{Järjestuskatse tulemuste analüüs mitmemõõtmelise skaleerimise ja tahkude teooria abil}

\subsection{Mitmemõõtmeline skaleerimine}

Mitmemõõtmeline skaleerimine (MDS) on 1950. aastatel alguse saanud statistiline analüüsimeetod. MDS-i esimesteks kasutajateks olid eksperimentaalpsühholoogid, kes vajasid tajukatsetega kogutud andmete analüüsimiseks ja analüüsitulemuste visualiseerimiseks sobivat vahendit (Davison 1988: 11). Hiljem on hakatud MDS-i kasutama keeruka struktuuriga andmete graafiliseks esitamiseks peale psühholoogia veel paljudes muudes uurimisvaldkondades, nt sotsioloogias, pedagoogikas, antropoloogias, geograafias, majandusuuringutes (Davison 1988: 13). MDS-i on rakendatud ka keeleteaduses, sh eesti keele uurimiseks (vt nt Kirt, Vainik 2007; Karjus 2012; Uusküla, Bimler 2016).

MDS võimaldab kirjeldada uuritavate objektide omavaheliste suhete struktuuri sel teel, et leiab distantsimaatriksile toetudes kõigi objektide paigutuse üksteise suhtes uurija poolt valitud dimensioonide arvuga (kõige sagedamini kahemõõtmelises) ruumis. Iga objekt on selles ruumilises mudelis tähistatud punktina ning punktidevahelised kaugused ruumis näitavad kas objektiivselt mõõdetud vahemaid (nt linnadevahelisi kaugusi) või subjektiivselt tajutud erinevusi (nt sisetunde alusel antud sarnasushinnangute puhul): suurem kaugus MDS-i lahenduses osutab suuremale vahemaale/erinevusele objektide vahel ja väiksem kaugus väiksemale vahemaale/erinevusele (Meyers jt 2006: 770).

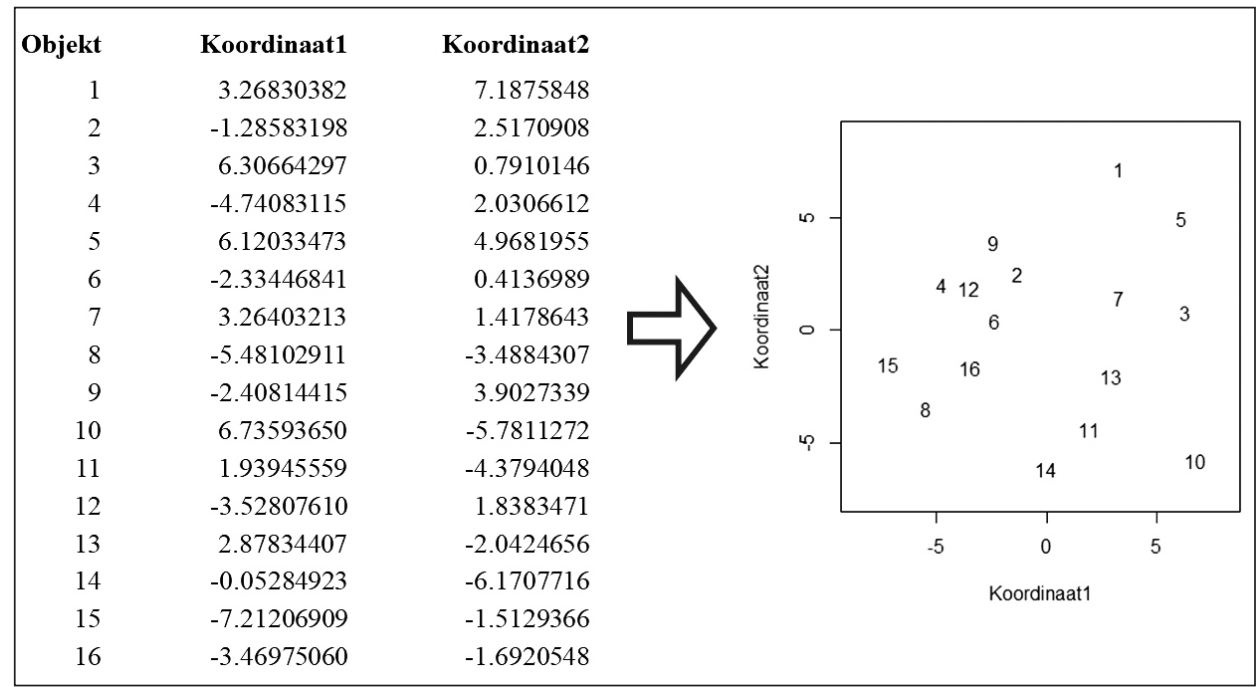

Joonis 5. Omadussõna vana järjestuskatse tulemuste (s.o katseisikute antud sarnasushinnangute) alusel loodud MDS-i lahendus, kus uuritavateks objektideks on introspektsioonipõhise mudeli 16 tähendust tabelist 2 . 
MDS-i lahenduse saamiseks leitakse kõigepealt distantsimaatriksis esitatud kaugustele toetudes objekte tähistavate punktide koordinaadid (vt joonise 5 vasakut poolt) ning seejärel paigutatakse punktid nende koordinaatide alusel vastava dimensioonide arvuga ruumi (vt kahemõõtmelist MDS-i lahendust joonise 5 paremal poolel, kus punktide asukohti märgivad numbrid).

Enne lõpplahenduse väljapakkumist on MDS-i algoritm tegelikult läbi proovinud mitmeid erinevaid punktide paigutamise võimalusi, püüdes leida tulemust, mis kajastaks kõige paremini uuritavate objektide omavahelisi suhteid. Seejuures hindavad erinevad MDS-i algoritmid leitud lahenduste headust pisut erinevatest põhimõtetest lähtudes. Ajalooliselt vanim ja loodusteadustes palju kasutatud klassikalise meetrilise MDS-i algoritm püüab luua mudelit, milles punktidevahelised kaugused vastaksid võimalikult täpselt esialgsetele objektidevahelistele kaugustele, samal ajal kui sotsiaal- ja humanitaarteadustes subjektiivsete kaugushinnangute uurimiseks rohkem kasutatavad mittemeetrilise MDS-i algoritmid püüavad säilitada MDS-i lahenduses üksnes esialgsete distantside järjestust, nt kui objektide A ja B vaheline kaugus algses distantsimaatriksis oli järjestuselt viies distants, siis peaks neile objektidele vastavate punktide vaheline kaugus MDS-i lahenduses olema kõigi punktipaaride vaheliste kauguste järjestuses samuti viiendal kohal (Bartholomew jt 2002: 59-60).

Omadussõna vana järjestuskatse tulemuste analüüsimiseks kasutasin 1969. aastal John W. Sammoni loodud MDS-i varianti, mis jääb klassikalise meetrilise ja mittemeetrilise MDS-i vahepeale, toetudes küll distantside arvulistele väärtustele (mitte üksnes järjestusele), kuid andes väiksemate distantside täpsemale kujutamisele suurema kaalu ning lubades suuremate distantside edasiandmisel suuremat ebatäpsust (Venables, Ripley 2002: 307-308; Sammon 1969). Sammoni meetodi kasuks otsustasin seetõttu, et minu uurimuses olid väga olulised just vana tähenduste lähinaabrussuhted (erinevused ainult ühe vastandpaari alusel).

\subsection{Tahkude teooria}

Pärast MDS-i lahenduse leidmist on järgmiseks sammuks selle tõlgendamine. Selleks on erinevaid võimalusi ning otsus, milline tõlgendusviis valida, sõltub paljuski sellest, mis eesmärgil MDS-meetodiga andmeid analüüsitakse: MDS-i võib kasutada nii andmetes peituva struktuuri esmaseks uurimiseks ja seal esinevate seoste avastamiseks kui ka varasemate teadmiste põhjal loodud hüpoteeside testimiseks (Borg, Groenen 1997: 6-9; Davison 1988: 19). Teoreetiliste seisukohtade alusel loodud mudeli paikapidavuse kontrollimiseks - nagu mina MDS-i kasutasin - sobib väga hästi tõlgendamisviis, kus MDS-i lahendust analüüsitakse tahkude teooriaga.

Tahkude teooria on 1950. aastate alguses Louis Guttmani algatusel empiiriliste teaduste jaoks loodud lähenemine, mis seisneb teooriast pärit mõisteliste kategooriate ja konkreetsete mõõtmistulemuste ühendamises mitmemõõtmelise statistilise andmeanalüüsi kaudu (Guttman, Greenbaum 1998: 13-15). Ingwer Borg ja Patric Groenen (1997: 72-73) on defineerinud tahku kui uuritava valdkonna elementide alamkategooriatesse klassifitseerimise skeemi, nt tahk „sugu” liigitab inimesed 
meesteks ja naisteks. Mingi teoreetilise seisukoha kontrollimiseks tahkude teooriaga püstitatakse hüpotees, mille järgi empiiriliste andmete põhjal saadud MDS-i lahendusruumi on võimalik liigendada sel viisil, et liigenduse igas alarühmas paiknevad teooriapõhise mudeli üht kindlat mõistelist kategooriat esindavad elemendid (Borg, Groenen 1997: 73), nt MDS-i lahenduses koonduvad ühte alarühma meessoost ja teise naissoost uurimisobjektid.

Kõige tüüpilisemate MDS-i lahenduse alarühmadeks liigendumise vormidena on Borg ja Groenen (1997: 83-84) toonud välja: 1) paralleelselt üksteise kõrval asetsevaid piirkondi eristava aksiaalse ehk telgliigenduse, 2) kontsentrilist paigutust kajastava modulaarse liigenduse ning 3) sektoriteks jagava polaarse liigenduse (vt joonist 6).

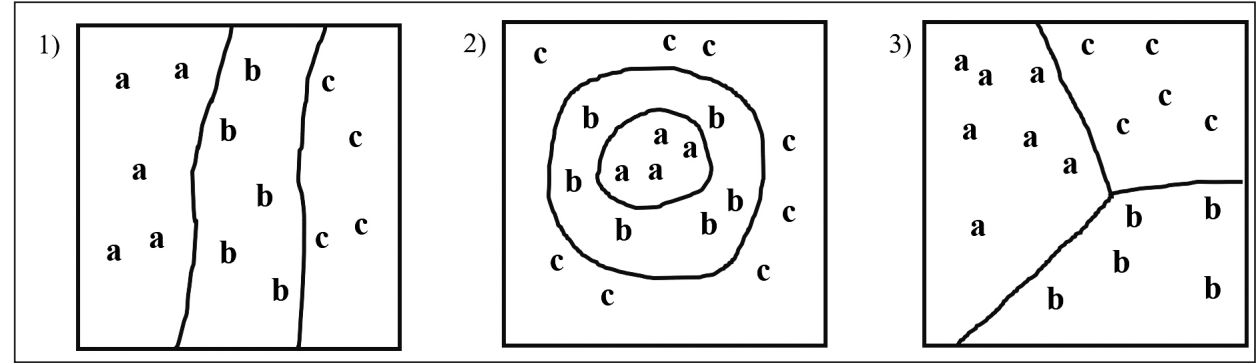

Joonis 6. Kõige tüüpilisemad MDS-i lahenduse alarühmadeks liigendumise vormid Borgi ja Groeneni (1997: 83) järgi: 1) aksiaalne, 2) modulaarne, 3) polaarne liigendus.

\subsection{Omadussõna vana järjestuskatse tulemuste analüüs}

Järjestuskatse tulemuste MDS-meetodiga analüüsimise eesmärk oli selgitada välja, kas katseisikute sarnasushinnangute alusel kahemõõtmelisse ruumi projitseeritud omadussõna vana tähenduste paigutuses ilmneb mingi korrapära, mida on võimalik seostada artikli esimeses osas tutvustatud introspektsioonipõhise mudeli aluseks olevate ajast arusaamise viisidega. Hüpotees, mida MDS-meetodiga kontrollisin, oli sõnastatud järgmiselt: keelekasutajad tajuvad introspektsioonipõhise mudeli iga vastandpaari samale ajast arusaamise viisile toetuvaid vana tähendusi omavahel rohkem kokku kuuluvat kui mitte samale ajast arusaamise viisile toetuvaid tähendusi. Hüpoteesi kehtivuse korral peaksid need kokkukuuluvused MDS-i lahenduses väljenduma alarühmade esiletulekuna.

Statistilise analüüsi teostasin rakendustarkvara R versiooni 3.5.3 abil (R Core Team 2019), kasutades MDS-i lahenduse loomiseks paketi „MASS” funktsiooni „sammon” (Ripley jt 2019: 133-134). Saadud lahenduse interpreteerimisel toetusin tahkude teooria põhimõtetele, käsitades oma analüüsis tahkudena omadussõna vana semantika introspektsioonipõhise mudeli nelja vastandpaari. Analüüsitulemused on esitatud joonisel 7. Alamjoonistel $7 \mathrm{a}-7 \mathrm{~d}$ on vana tähendustele vastavad numbrid (vt numbrite tähendusi tabelist 2) kantud joonisele selle värviga (mustaga või halliga), kummale vastandpaari poolele nad introspektsioonipõhises mudelis toetuvad. 


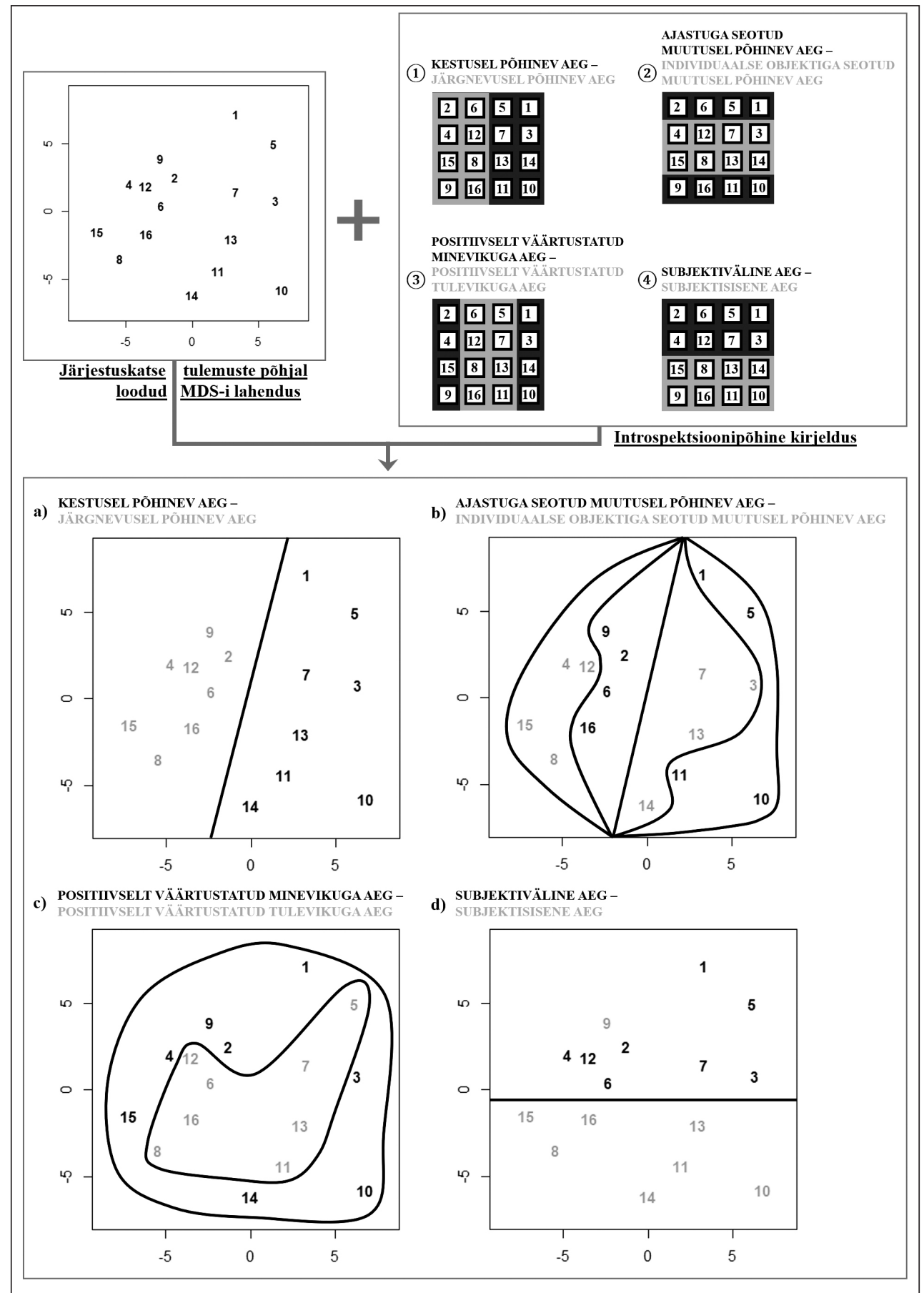

Joonis 7. Omadussõna vana järjestuskatse tulemuste põhjal loodud MDS-i lahenduse seosed introspektsioonipõhise mudeli ajast arusaamise viiside nelja vastandpaariga. 
Joonisel 7 on näha, milliseid introspektsioonipõhise mudeliga kooskõlas olevaid alarühmi on võimalik katsetulemustes eristada.

a) Keelekasutajad tajuvad tõepoolest introspektsioonipõhises mudelis KESTUSEL PÕHINEVALE AJALE toetuvate vana tähenduste $1,3,5,7,10,11,13$ ja 14 (nt vana naine) erinevust JÄRGNEVUSEL PÕHINEVALE AJALE toetuvatest tähendustest 2, 4, 6, 8, 9, 12, 15 ja 16 (nt vana juhataja), kuna need on võimalik üksteisest selgelt eristada tähendusvälja poolitava telje abil (vt joonist 7a). Seega võib seda vastandpaari pidada oluliseks tunnuseks vana tähenduste üksteisest eristamisel.

b) AJASTUGa SEOTUd MUUTUSEL PÕHINEVA AJA ja INDIVIDUAALSE OBJEKTIGA SEOTUD MUUTUSEL PÕHINEVA AJA seos vana tähenduste tähendusväljale paigutumisega ei ole nii ilmne, kui see oli esimesel vastandpaaril, kuna sama värviga märgitud tähendused ei koondu joonisel $7 \mathrm{~b}$ selgelt ühte kohta kokku. Põhjalikumal analüüsimisel on aga võimalik eristada nelja sektorit. Selleks tuleb tähendusväli kõigepealt jagada pooleks esimese vastandpaari sirge telje abil ja seejärel saab mõlemal poolel eristada omakorda kaht alarühma $a^{5}$ keskteljest vasakule poole jääval alal koonduvad mustade numbritega märgitud AJASTUGA SEOTUD MUUTUSEL PÕHINEVALE AJALE toetuvad tähendused 2, 6, 9 ja 16 (nt vana kaevandamismeetod) keskteljele lähemale ning hallide numbritega märgitud INDIVIDUAALSE OBJEKTIGA SEOTUD MUUTUSEL PÕHINEVALE AJALE toetuvad tähendused 4, 8, 12 ja 15 (nt vana juhataja) hoiavad rohkem tähendusvälja ääre poole. Keskteljest paremale poole jääval alal on aga vastupidi hallide numbritega märgitud INDIVIDUAALSE OBJEKTIGA SEOTUD MUUTUSEL PÕHINEVALE AJALE toetuvad tähendused 3, 7, 13 ja 14 (nt vana naine) paiknevad keskteljele lähemal ning mustade numbritega märgitud AJASTUGA SEOTUD MUUTUSEL PÕHINEVALE AJALE toetuvad tähendused 1, 5, 10 ja 11 (nt vana $k u u$ ) hoiavad rohkem tähendusvälja äärele.

Tähendus 11 'sama, mis enne' asub küll äärealast natuke kaugemal, kuid nagu laiema uurimuse raames ka teiste katsete ja analüüsimeetodite tulemused näitasid (Pikksaar 2016), ${ }^{6}$ kaldub tähendus 11 moodustama (vähemalt siinses uurimuses kasutatud katselausete korral) oma introspektsioonipõhise mudeli naabertähendusega 13 'tuntud' liittähendust, mille puhul ei ole oluline eristada AJASTUGA SEOTUD MUUTUSEL PÕHINEVAT ja INDIVIDUAALSE OBJEKTIGA SEOTUD MUUTUSEL PÕHINEVAT AEGA. Teisiti öeldes võiks tähenduste 11 ja 13 vahelise piiri introspektsioonipõhisest mudelist eemaldada. See tulemus võib olla mõjutatud konkreetsetest katselausetest, aga ei pruugi, sest keelekasutajate jaoks võib-olla tõesti ei olegi olulised kõik teoreetiliselt võimalikud eristused.

Tulemuste põhjal saab seega öelda, et see vastandpaar ei ole vana tähenduste eristamisel esmase tähtsusega, kuid võimaldab siiski mingil määral tähenduste omavahelisi suhteid seletada.

\footnotetext{
${ }^{5}$ Vajadus jagada selles vastandpaaris vana tähenduste kirjeldused erinevalt teistest paaridest mitte kahte, vaid nelja rühma ilmnes juba introspektsioonipõhise mudeli loomisel (vt tabelit 1). ${ }^{6}$ Seal oli peale järjestuskatse kasutatud veel vaba sorteerimise katset ja hierarhilise sorteerimise katset ning analüüsimeetoditest lisaks MDS-ile veel hierarhilist klasteranalüüsi ja minimaalse täispuu meetodit.
} 
c) PositiIVSElt VÄ̈̈RTUSTATUd TUleViKuga AJAle toetuvad vana tähendused 5, 6, 7, $8,11,12,13$ ja 16 (nt vana kaevandamismeetod) koonduvad rohkem tähendusvälja keskele ning POSITIIVSELT VÄÄRTUSTATUD MINEVIKUGA AJALE toetuvad tähendused 1, 2, 3, 4, 9, 10, 14 ja 15 (nt vana tegija) jäävad rohkem äärealadele (vt joonist 7c). Tähendus 5 'hääbuv', mis jääb teistest tähendusvälja keskosas asuvatest POsITIIvSELT VÄÄRTUSTATUD TULEVIKUGA AJALE toetuvatest tähendustest kaugemale, tuleks ühendada liittähenduseks tema introspektsioonipõhise mudeli naabertähendusega 1 'taaslõppev'. Ülejäänud tähenduste juures võib aga näha tendentsi paigutuda kas tähendusvälja keskme poole või sellest kaugemale olenevalt sellest, kummale paari liikmele toetuva tähendusega on tegemist. Seetõttu võib järeldada, et vana tähenduste eristamisel võtavad keelekasutajad mingil määral arvesse ka selle vastandpaariga seostatavat tunnust.

d) SUBJEKTIVÄLISELE AJALE toetuvad tähendused 1, 2, 3, 4, 5, 6, 7 ja 12 (nt vana särk) ning SUBJEKTISISESELE AJALE toetuvad tähendused $8,10,11,13,14,15$ ja 16 (nt vana nali) saab üsna selgelt üksteisest eristada ühe telje abil (vt joonist 7d) - peale tähenduse 9 'kunagine', mis introspektsioonipõhises mudelis toetub SUBJEKTISISESELE AJALE, kuid katseandmete järgi kuulub kokku hoopis SUBJEKTIVÄLISELE AJALE toetuvate tähendustega. See on seletatav sellega, et ta hoiab tugevasti oma introspektsioonipõhise mudeli naabri, tähenduse 2 'endisaegne' lähedusse. Nagu eespool mainitud (vt nt joonist 3), keerduvad introspektsioonipõhises mudelis tähendusvälja alumine ja ülemine äär kokku, nii et tähendused 2 ja 9 on vahetud naabrid, mille vahelt on võimalik piir eemaldada, asendades need ühe liittähendusega, mis ei tee vahet objektiivse vaatluse ja subjektiivsete teadmiste alusel objekti vanaks tunnistamisel. Kokkuvõttes võib aga ka vastandpaari SUBJEKTIVÄLINE AEG - SUBJEKTISISENE AEG üsna kindlalt seostada tunnusega, millele keelekasutajad intuitiivselt toetuvad sõna vana tähenduste võrdlemisel.

\section{Arutelu}

Uurimus otsis järjestuskatsega kinnitust introspektsioonipõhise semantilise kirjelduse aluseks olnud oletusele, mille järgi omadussõna vana tähenduse varieerumine on tingitud sellest, et erinevates kasutusolukordades toetuvad keelekasutajad erinevatele aja kohta käivatele või ajaga seostuvatele arusaamadele. Katseandmete statistiliseks analüüsimiseks kasutatud mitmemõõtmelise skaleerimise metoodikale tuginev Sammoni meetod koos tahkude teoorial põhineva tõlgendamisviisiga kinnitas uurimishüpoteesi: katsetulemuste põhjal loodud omadussõna vana tähendusväljal oli võimalik eristada kõigi introspektsioonipõhisesse mudelisse kuuluvate ajast arusaamise viisidega seostatavaid alarühmi. Kõige tugevamini seostus vana semantikaga vastandpaar KESTUSEL PÕHINEV AEG - JÄRGNEVUSEL PÕHINEV AEG. Teiste vastandpaaride seos vana tähendustega oli katsetulemuste põhjal natuke nõrgem, kuna tähendusväljal leidus üksikuid piirkondi, mille tähenduserinevusi keelekasutajad ei tajunud, kuigi introspektsioonipõhise mudeli järgi oleksid võinud tajuda. 
Tulemused lubavad järeldada, et introspektsioonipõhises kirjelduses väljatoodud ajast arusaamise viiside vastandpaare võib pidada sobivateks tunnusteks, mille alusel vana võimalikke tähendusi üksteisest eristada. St omadussõna vana erinevate tähenduste olemasolu saab põhjendada sellega, et nende aluseks on erinevad arusaamad ajast. Ma ei arva, et siin väljapakutu oleks ainus viis vana polüseemia seletamiseks, aga see on üks võimalus - näha mingit korrapära ja süsteemseid seoseid selle sõna tähenduste paljususe taga, toetudes kognitiivlingvistilisest vaatepunktist lähtudes teadmistele sellest, kuidas keelekasutajad mõistavad maailma ja maailmas toimuvat.

Introspektiivne analüüs oli siin uurimuses üles ehitatud vastandustele (tähendusi aitasid eristada ajast arusaamise viiside vastandpaarid), kuid selle asemel võib lähtuda ka muust põhimõttest. Samas omadussõnade puhul võiks just vastandustel põhinev lähenemine tulevasteski uurimustes sobiv olla, kuna omadussõnade semantikas on opositsioonidel väga tähtis roll (nt antonüümia on üks olulisim adjektiivide leksikaalsete suhete liik).

Kasutatud meetodid võimaldasid välja tuua põhimõtted, mille alusel vana tähendustel vahet teha. Kuid 16 katselauset on liiga vähene keelematerjal, et selle põhjal otsustada, milliseid tähendusvälja piirkondi võiks või tuleks eraldiseisvate üksustena eristada (kuigi kohati ilmnes vajadus ühendada mõned introspektsioonipõhise mudeli naaberalad). Keelekasutajate mentaalses leksikonis üksuse staatust omada võivate tähendusvälja piirkondade väljaselgitamiseks ja põhjalikumaks uurimiseks võiks edaspidi kombineerida katseid korpusanalüüsi meetoditega.

\section{Kokkuvõte}

Artikli eesmärk oli tutvustada järjestuskatse kui semantikaalases uurimistöös uudse katsetüübi kasutamise võimalust polüseemse sõna niisuguse semantilise kirjelduse loomisel, mis kajastaks, kuidas emakeelekõnelejad tähendustel vahet teevad. Järjestuskatse oli siin vahend, mille abil koguda keelekasutajate hinnanguid uuritava omadussõna vana tähenduste erinevustele. Oluliseks uurimisprotsessi osaks oli katse läbiviimisele eelnenud omadussõna vana semantika introspektiivne analüüs, mille tulemused said aluseks katsega kontrollitava hüpoteesi püstitamisele ja sobiva katsematerjali valimisele. Katsetulemuste analüüsimiseks kasutatud mitmemõõtmelise skaleerimise meetod paigutas kõik vana tähendused tajutud sarnasuse alusel kahemõõtmelisse ruumi, kus tähendused, mida katseisikud tajusid sarnasematena, paiknesid üksteisele lähemal, ja tähendused, mida tajuti erinevamatena, paiknesid üksteisest kaugemal. Edasi sai tahkude teooriale toetudes kontrollida, milliseid introspektsioonipõhise mudeli kategooriatega (s.o vana tähenduste eristamisel oluliseks peetud ajast arusaamise viisidega) seostatavaid alarühmi oli võimalik selles kahemõõtmelises ruumis vana tähenduste paiknemise alusel eristada.

Hüpotees, et vana erinevate tähenduste olemasolu on seotud erinevate ajast arusaamise viisidega, leidis uurimuse käigus kinnitust, kuna mitmemõõtmelise skaleerimise lahenduses õnnestus leida introspektsioonipõhise mudeli kõigi kategooriatega seostatavaid alarühmi. See omakorda näitab, et järjestuskatse on sobiv vahend 
niisuguste andmete kogumiseks, mis võimaldavad avada põhimõtteid, millele emakeelekõnelejad polüseemse sõna tähenduste võrdlemisel intuitiivselt toetuvad. Seega võib sõna vana uurimiseks kasutatud andmekogumis- ja andmeanalüüsimeetodite komplekti (introspektsioon + järjestuskatse + mitmemõõtmeline skaleerimine + tahkude teooria) soovitada ka teiste mitmetähenduslike (omadus)sõnade sellise semantilise kirjelduse loomiseks, mis oleks kooskõlas sellega, kuidas keelekasutajad nende sõnade tähendusi eristavad.

Artiklis tutvustatud uurimisvahend sobib praegusel kujul polüseemse sõna semantilise süvaanalüüsi tegemise jaoks, selleks et uurida inimmõtlemise ja keeleliste tähenduste vahelisi seoseid kognitiivlingvistilisest aspektist. Edaspidi võiks aga järjestuskatse kombineerimine korpusmeetoditega aidata välja töötada näiteks leksikograafi abivahendi semantikaalases praktilises töös kasutamiseks.

Artikli valmimist on toetanud Sihtasutus Eesti Teadusagentuur (PUT1358 „Mudelite loomine ja lõhkumine: klassifitseerimismudelite valideerimine keeleteaduses").

\section{KIRJANDUS}

Aarelaid, Aili 1977. Ajastud ja ajamõistmine. - Looming, nr 2, lk 302-313.

Aristotle 1993. Physics. Books III and IV. Tlk Edward Hussey. Oxford: Clarendon Press.

Bartholomew, David J.; Steele, Fiona; Moustaki, Irini; Galbraith, Jane I. 2002. The Analysis and Interpretation of Multivariate Data for Social Scientists. London: CRC Press.

Borg, Ingwer; Groenen, Patrick 1997. Modern Multidimensional Scaling: Theory and Applications. New York: Springer.

Bouillon, Pierrette 1999. The adjective 'vieux': The point of view of 'Generative Lexicon'. Breadth and Depth of Semantic Lexicons. Toim Evelyne Viegas. Dordrecht: Kluwer Academic Publishers, lk 148-166.

Davison 1988 = Mark L. Dèjvison, Mnogomernoe škalirovanie: metody nagljadnogo predstavlenija dannyh. Moskva: Finansy i statistika. [Марк Л. Дэйвисон, Многомерное шкалирование: методы наглядного представления данных. Москва: Финансы и статистика.]

EKSS = Eesti keele seletav sõnaraamat. Kd 1-6. „Eesti kirjakeele seletussõnaraamatu” 2., täiendatud ja parandatud trükk. Toim Margit Langemets, Mai Tiits, Tiia Valdre, Leidi Veskis, Ülle Viks, Piret Voll. Eesti Keele Instituut. Tallinn: Eesti Keele Sihtasutus, 2009.

Geeraerts, Dirk 1993. Vagueness's puzzles, polysemy's vagaries. - Cognitive Linguistics, kd 4, nr 3, lk 223-272.

Gurevitš 1968 = Aron Gurevič, Čto est' vremja? - Voprosy literatury, nr 11, lk 151-174. [Арон Гуревич, Что есть время? - Вопросы литературы, 11, 151-174.]

Gurevitš, Aron 1992. Keskaja inimese maailmapilt. Tlk Einar Laigna. Tallinn: Kunst.

Guttman, Ruth; Greenbaum, Charles W. 1998. Facet theory: Its development and current status. - European Psychologist, kd 3, nr 1, lk 13-36.

Ingold, Tim 1986. Evolution and Social Life. Cambridge: Cambridge University Press.

Jürine, Anni; Klavan, Jane; Veismann, Ann 2013. Katseline semantika: planeerimine ja teostus. - Eesti Rakenduslingvistika Ühingu aastaraamat, nr 9, lk 85-100. 
Karjus, Andres 2012. OUT in Estonian, Võro, Latvian and Lithuanian: A Usage-Based Approach to the Grammaticalization and Gradience of Spatial Grams of the exteriorregion. Master's Thesis. Tartu: University of Tartu.

Kirt, Toomas; Vainik, Ene 2007. Comparison of the methods of self-organizing maps and multidimensional scaling in analysis of Estonian emotion concepts. - Proceedings of the 16th Nordic Conference of Computational Linguistics. Toim Joakim Nivre, Heiki-Jaan Kaalep, Kadri Muischnek, Mare Koit. Tartu: University of Tartu, lk 113-120.

Klavan, Jane; Veismann, Ann; Jürine, Anni 2013. Katselised meetodid tähenduse uurimisel. - ESUKA/JEFUL, kd 4, nr 1, lk 17-34.

Klein 1999 = Lev Samojlovič Klejn, Koncepcii vremeni v tradicionnoj kul'ture. - Vremja i kalendar' v tradicionnoj kul'ture. Tezisy dokladov vserossijskoj naučnoj konferencii. Sankt-Peterburg: Lan', lk 3-9. [Лев Самойлович Клейн, Концепции времени в традиционной культуре. - Время и календарь в традиционной культуре. Тезисы докладов Всероссийской научной конференции. Санкт-Петербург: Лань, 3-9.]

Kruskal, Joseph B.; Wish, Myron 1978. Multidimensional Scaling. Newbury Park, California: Sage Publications.

Mellor, David Hugh 2003. Aeg meie elus. Tlk Maris Kaskmann. - Akadeemia, nr 5, lk 958976.

Meyers, Lawrence S.; Gamst, Glenn C.; Guarino, Anthony J. 2006. Applied Multivariate Research: Design and Interpretation. Thousand Oaks: Sage Publications.

Pikksaar, Aimi 2012. Omadussõna vana semantika süsteemne kirjeldus ajast arusaamise viiside taustal. Bakalaureusetöö. Tartu: Tartu Ülikooli eesti keele osakond. http://www. murre.ut.ee/arhiiv/naita_pilt.php?materjal=kasikiri\&materjal_id=D1757\&sari=D (29. X 2019).

Pikksaar, Aimi 2016. Omadussõna vana semantiline analüüs katseliste meetodite abil. Magistritöö. Tartu: Tartu Ülikooli üldkeeleteaduse osakond. https://dspace.ut.ee/handle/10062/54060 (29. X 2019).

R Core Team 2019. R: A language and environment for statistical computing. Vienna: R Foundation for Statistical Computing. http://www.R-project.org/ (29. X 2019).

Rahhilina 1997 = Ekaterina Vladimirovna Rahilina, O starom: aspektual'nye harakteristiki predmetnyh imen. - Logičeskij analiz jazyka: jazyk i vremja. N. D. Arutjunova, T. E. Janko. Moskva: Indrik, lk 201-218. [Екатерина Владимировна Рахилина, О старом: аспектуальные характеристики предметных имен. - Логический анализ языка: язык и время. Н. Д. Арутюнова, Т. Е. Янко. Москва: Индрик, 201-218.]

Rao, Vithala R.; Katz, Ralph 1971. Alternative multidimensional scaling methods for large stimulus sets. - Journal of Marketing Research, kd 8, nr 4, lk 488-494.

Ravin, Yael; Leacock, Claudia 2000. Polysemy: An overview. - Polysemy: Theoretical and Computational Approaches. Toim Y. Ravin, C. Leacock. Oxford: Oxford University Press, lk 1-29.

Ripley, Brian; Venables, Bill; Bates, Douglas M.; Hornik, Kurt; Gebhardt, Albrecht; Firth, David 2019. Package 'MASS'. https://cran.r-project.org/web/packages/MASS/MASS.pdf (29. X 2019).

Sammon, John W. 1969. A nonlinear mapping for data structure analysis. - IEEE Transactions on Computers, kd C-18, nr 5, lk 401-409. 
Sandra, Dominiek; Rice, Sally 1995. Network analyses of prepositional meaning: Mirroring whose mind - the linguist's or the language user's? - Cognitive Linguistics, kd 6, nr 1, lk 89-130.

Taylor, John R. 1992. Old problems: Adjectives in cognitive grammar. - Cognitive Linguistics, kd 3, nr 1, lk 1-35.

Taylor, John R. 2003. Polysemy's paradoxes. - Language Sciences, nr 25, lk 637-655.

Tooding, Liina-Mai 2015. Andmete analüüs ja tõlgendamine sotsiaalteadustes. Tartu: Tartu Ülikooli Kirjastus.

Tsogo, Léopold; Masson, Marie-Hélène; Bardot, Anne 2000. Multidimensional scaling methods for many-object sets: A review. - Multivariate Behavioral Research, kd 35, nr 3, lk 307-319.

TÜKK = Tartu Ülikooli eesti kirjakeele korpus. https://www.cl.ut.ee/korpused/ (10. II 2016).

Uusküla, Mari; Bimler, David 2016. From listing data to semantic maps: Crosslinguistic commonalities in the cognitive representation of colour. - Folklore: The Electronic Journal of Folklore, nr 64, lk 57-90.

Vahtre, Lauri 1991. Eestlase aeg: uurimus eesti rahvapärase ajaarvamise ajaloost. Tallinn: Eesti Teaduste Akadeemia.

Veismann, Ann; Klavan, Jane; Õim, Haldur 2018. Teoreetiline keeleteadus ja kvantitatiivsed meetodid. - Keel ja Kirjandus, nr 8-9, 1k 609-621.

Venables, William N.; Ripley, Brian D. 2002. Modern Applied Statistics with S. New York: Springer.

Õim, Haldur 1990. Kognitiivne lähenemine keeleteaduses. - Akadeemia, nr 9, lk 1818-1838.

Õim, Haldur 1997. Eesti keele mentaalse maailmapildi allikaid ja piirjooni. - Pühendusteos Huno Rätsepale 28.12.1997. (Tartu Ülikooli eesti keele õppetooli toimetised 7.) Toim Mati Erelt, Meeli Sedrik, Ellen Uuspõld. Tartu: Tartu Ülikooli Kirjastus, lk 255-268.

Aimi Pikksaar (snd 1976), MA, Tartu Ülikooli eesti ja üldkeeleteaduse instituudi doktorant (Jakobi 2, 51005 Tartu), aimi.pikksaar@ut.ee

\section{Ranking task as a tool for studying polysemy: A case study of the Estonian adjective vana 'old'}

Keywords: cognitive linguistics, semantics, introspection, experimental methods, multidimensional scaling, facet theory

The aim of the article is to introduce a combination of research methods for studying polysemy. Ranking task is the central tool of this methodological combination, which enables creation of a semantic description that reflects how language users distinguish meanings of the studied word. For introducing the research process I used the Estonian adjective vana 'old' as an example. At the beginning of the study, I made the assumption that different senses of the adjective vana are related to different interpretations of time. Introspective analysis of the semantics of the adjec- 
tive vana included four pairs of opposite time interpretation models. In the ranking task, participants were asked to rank the meanings of vana in different sentences in order of their similarity to the meaning of vana in different reference stimulus sentences. The hypothesis was that those senses of vana which are related to the same time interpretation model would be perceived by participants as being more similar to each other than those which are not related to the same time interpretation model. For analysing the data gathered with the ranking task, I used multidimensional scaling and facet theory. The results of the analysis confirmed the assumption that it is possible to explain the variation of the meaning of the adjective vana on the basis of different interpretations of time. Hence, I concluded that the combination of research methods used here (introspection + ranking task + multidimensional scaling + facet theory) is an appropriate tool for studying polysemy and can be suggested for analysing the semantics of other polysemous words as well.

Aimi Pikksaar (b. 1976), MA, PhD Student at University of Tartu, Institute of Estonian and General Linguistics (Jakobi 2, 51005 Tartu), aimi.pikksaar@ut.ee 